\title{
ARTYKULY
}

\section{KWESTIA OBSADY STANOWISK MAGISTRÓW MILITUM ZA PANOWANIA CESARZA ZENONA (474-491)1}

\author{
MirOSŁAW J. LESZKA
}

\begin{abstract}
The Question of assigning the posts of Magistri Militum during the reign of emperor Zeno (474-491). Originating from Isauria, Emperor Zeno was a ruler who struggled more against internal opponents who made attempts to deprive him of power (usurpations of Basiliskos 475-476, Martian 479, Illus and Leontius 484-488) than against external enemies. Zeno's career, before becoming a ruler, was of a military nature. He was certainly a comes domesticorum and magister militum per Orientem, and some scholars believe that he may also have held the position of magister militum per Thracias and magister militum praesentalis. The aim of the article is to make an attempt to answer the question what the emperor, who had rich military experience, was guided by when appointing magistri militum. A review of the available information concerning the appointment of magistri militum by Zeno leads to the conclusion that these posts were a means of recruiting or rewarding people whose support the emperor needed for some reason. The highest positions of command were relatively often given to members of the imperial family or the families of influential personalities at the imperial court or their protégés.
\end{abstract}

Streszczenie. Kwestia obsady stanowisk magistrów militum za panowania cesarza Zenona (474-491). Wywodzący się z Izaurii cesarz Zenon, to władca zmagający się bardziej z wewnętrznymi przeciwnikami, którzy podejmowali próby odebrania mu władzy (uzurpacje Bazyliskosa 475-476, Marcjana 479, Illusa i Leoncjusza 484-488) niż z wrogami zewnętrznymi. Kariera Zenona, zanim został władcą miała charakter wojskowy. Z pewnością był komesem domesticorum i magistrem militum per Orientem, a część uczonych uważa, że mógł zajmować również stanowisko magistra militum per Thracias oraz magistra militum praesentalis. Celem artykułu jest próba odpowiedzi na pytanie czym kierował się dysponujący bogatym wojskowym doświadczeniem cesarz przy powoływaniu magistrów militum. Przegląd dostępnych informacji, dotyczących powoływania magistrów militum przez Zenona prowadzi do wniosku, że stanowiska te były środkiem do pozyskiwania lub wynagradzania ludzi, których wsparcie było z jakichś względów potrzebne cesarzowi. Najwyższe stanowiska dowódcze stosunkowo często rozdawane były członkom cesarskiej rodziny czy rodzin wpływowych osobistości na dworze cesarskim względnie ich protegowanych. Trzeba zaznaczyć, że kandydaci na magistrów militum dysponowali najczęściej jakimś wojskowym doświadczeniem, ale nie musiało być ono szczególnie bogate.

Author: Mirosław J. Leszka, Uniwersytet Łódzki, Wydział Filozoficzno-Historyczny, Instytut Historii, Katedra Historii Bizancjum, ul. Kamińskiego 27a, 90-219 Łódź, e-mail: miroslaw.leszka@uni.lodz.pl

ORCID iD: https://orcid.org/0000-0003-2643-4520

Keywords: Byzantium, emperor Zeno, magistri militum

Słowa kluczowe: Bizancjum, cesarz Zenon, magistrzy militum

Balcanica Posnaniensia. Acta et studia, XXVIII/2, Poznań 2021, Wydawnictwo Wydziału Historii UAM, pp. 5-22, ISBN 978-83-66355-84-2, ISSN 0239-4278. Polish text with summaries in English and Polish

1 Niniejszy tekst powstał $\mathrm{w}$ ramach projektu sfinansowanego z środków Narodowego Centrum Nauki, przyznanych na podstawie decyzji nr DEC-2018/31/B/HS3/03038 (Wschodniorzymskie elity wojskowe od Teodozjusza II do Anastazjusza I (408-518). Studium spoleczno-polityczne). 
doi.org/10.14746/bp.2021.28.16

Wywodzący się z Izaurii cesarz Zenon, to władca zmagający się bardziej z wewnętrznymi przeciwnikami, którzy podejmowali próby odebrania mu władzy (uzurpacje Bazyliskosa 475-476, Marcjana 479, Illusa i Leoncjusza 484-488) niż z wrogami zewnętrznymi ${ }^{2}$. Zanim został władcą, formalnie wyniesionym na tron przez Leona II, swojego małoletniego syna, jego kariera miała charakter wojskowy. Z pewnością był komesem domesticorum i magistrem militum per Orientem, a część uczonych uważa, że mógł zajmować również stanowisko magistra militum per Thracias oraz magistra militum praesentalis ${ }^{3}$. Z doświadczenia więc wiedział jaka odpowiedzialność spoczywa na najwyższych dowódcach armii bizantyńskiej, jaki jest ich zakres obowiązków i jakimi kompetencjami winni się wykazywać. Mogło to, ale nie musiało wpływać na podejmowane przez niego decyzje w zakresie obsadzania najwyższych stanowisk dowódczych, a mianowicie magistrów militum ${ }^{4}$ : praesentalis, per Orientem, per Thracias i per Illyricum.

Celem prezentowanego artykułu jest próba odpowiedzi na pytania jaki był wpływ cesarza na obsadę stanowisk magistrów militum i czym kierował się przy podejmowaniu decyzji w tej kwestii.

2 Na temat rządów Zenona patrz: P. Crawford, Roman Emperor Zeno: The Perils of Power Politics in Fifth-century Constantinople, Yorkshire-Philadelphia 2019; R. Kosiński, The Emperor Zeno. Religion and Politics, Cracow 2010. O uzurpacji Bazyliskosa, która często pojawiać się będzie w niniejszym tekście patrz m.in. M. J. Leszka, Empress-Widow Verina's Political Activity during the Reign of Emperor Zeno, [w]: Mélanges d'histoire byzantine offerts à Oktawiusz Jurewicz à l'occasion de son soixante-dixième Anniversaire, red. W. Ceran, Łódź 1998, s. 128-136; idem, Illus Izauryjczyk wobec uzurpacji Bazyliskosa, „Acta Universitais Lodziensis. Folia Historica” 2005, nr 80, s. 45-49; K. Twardowska, Cesarzowe bizantyńskie 2 pot. V w. Kobiety i władza, Kraków 2009, s. 109-124; R. Kosiński, The Emperor Zeno, s. 7982.

3 Na temat kariery Zenona do czasów przejęcia tronu zobacz: J. R. Martindale, The Prosopography of the Later Roman Empire, t. 2, A.D. 395-527, Cambridge 1980, s. 717 [dalej: PLRE II], s. 1200-1202; R. Kosiński, Początki kariery Tarasikodissy-Zenona, [w:] Byzantina Europea. Księga jubileuszowa ofiarowana Profesorowi Waldemarowi Ceranowi, Łódź 2007, s. 289-304; idem, The Emperor Zeno, s. 57-72 (autor przedstawia ważkie argumenty na rzecz poglądów, że Zenon albo nie był magistrem militum per Thracias, albo był nim bardzo krótko i nie zajmował stanowiska magistra militum praesentalis).

${ }^{4}$ Na temat stanowiska magister militum:A. Demandt, Magister militum, [w:] Paulys Realencyclopädie der classischen Altertumswissenschaft [dalej: RE]. Supplementband XII, Stuttgart 1970, kol. 553-790; E. P. Glushanin, Voennaja znat'rannej Vizantii, Barnaul 1991; A. Poguntke, Das römische Heermeisteramt im 5. Jahrhundert. Überlegungen zum Verhältnis zwischen Kaiser und Heermeister in Ost und West, [w:] Osten und Westen 400-600 n. Chr. Kommunikation, Kooperation und Konflikt, red. C. Föller, F. Schulz, Stuttgart 2016, s. 239-262; A.-K. Wassiliou-Seibt, From magister militum to strategos: the evolution of the highest military commands in early Byzantium (5th-7th c.), „Travaux et Mémoires” 2017, t. 21, nr 1,

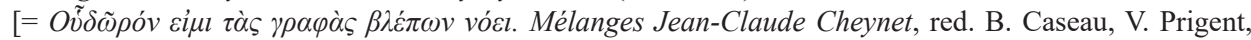
A. Sopracasa, Paris 2017], s. 789-802. 
Zenon w okresie swoich rządów wyznaczył, według dostępnego nam materiału źródłowego kilkunastu magistrów militum ${ }^{5}$. Ich wyniesienia zostaną przeanalizowane w obrębie najpierw magistrów militum praesentalis (I i II armia in praesenti), a następnie per Orientem, per Illyricum i wreszcie per Thracias.

\section{MAGISTRI MILITUM PRAESENTALIS \\ I ARMIA IN PRAESENTI}

\section{Marcjan - 471/474}

Marcjan, w chwili przejęcia władzy przez Zenona, co nastąpiło najpewniej 28 stycznia 474 r., zajmował stanowisko magistra militum praesentalis, które powierzył mu Leon I, jego teść 6 . Zenon, jak się wydaje, uznał ten stan rzeczy. Marcjan był synem Antemiusza, który przez kilka lat sprawował władzę w zachodniej części Imperium Romanum i Marcji Eufemii, córki cesarza Marcjana (450-457). Z tytułu znakomitego pochodzenia cesarz Leon I wydał za niego Leoncję, swoją córkę. Powierzano mu ważne stanowiska i obdarzano najwyższymi tytułami (był patrycjuszem, dwukrotnym konsulem, w 469 i 472 r.). Leon I powierzył mu w końcu swoich rządów stanowisko magistra militum praesentalis.

5 Wykaz magistrów militum z czasów Zenona: PLRE II, s. 1290-1293. Poza obrębem rozważań pozostawiam powierzanie stanowiska magistra militum praesentalis Teodorykowi Strabonowi i Teodorykowi Amalowi, władcom Ostrogotów. W ich przypadku stanowisko to, za którym szło wysokie wynagrodzenie, miało charakter honorowy i stanowiło narzędzie do neutralizowania zagrożenia ze strony Ostrogotów. Nie można ich nominacji traktować jako normalnej procedury realizowanej przez władcę w obrębie kadry dowódczej. Ani Teodoryk Strabon, ani Teodoryk Amal po otrzymaniu stanowiska nie dowodził wschodniorzymskimi oddziałami. E. P. Glushanin, Voennaja, s. 147. Gwoli porządku odnotować wypada, że Teodoryk Strabon był magistrem militum praesentalis trzykrotnie (473-474; 475/476, 478479), a Teodoryk Amal dwukrotnie (476-478, 483-487).

Wątpliwym wydaje się, żeby niejaki Idubingus w jakimś okresie między 466 a 493 był magistrem militum praesentalis (PLRE II, s. 585-586). Sam fakt datowania wydarzeń przez autora Żywota Daniela Stylity (Vita S. Danielis Stylitae, 64, red. H. Delehaye, ,Analecta Bollandiana” 1913, nr 37 [dalej: Żywot Daniela Stylity] przez wskazanie, że stało się to wtedy, kiedy Idubingus był stratelatesem ( $\sigma \tau \rho \alpha \tau \eta \lambda \alpha ́ \tau \eta \varsigma$, termin ten używany był na określenie magistrów militum; por. np. J. Durliat, Magister militum - stratelates dan l'Empire Byzantin (VIe-VIIe siècles), „Byzantinische Zeitschrift” 1979, t. 72, s. 306-320) jest, w moim przekonaniu, niewystarczającym argumentem na rzecz uprawdopodobnienia sprawowania przez niego wzmiankowanej powyżej funkcji.

6 Podstawowe informacje na temat Marcjana: W. Ensslin, Marcianus 35, [w:] RE, Bd. XIV, 2 , Stuttgart 1956, kol. 1519; PLRE II, s. 717-718; Ch. Begass, Die Senatsaristokratie des oströmischen Reiches, ca. 457-518. Prosopographische sozialgeschichtliche Untersuchungen, München 2018, s. 185186 (wątpi w fakt pełnienia przez Marcjana stanowiska magistra militum praesentalis). O sprawowaniu przez Marcjana stanowiska magistra militum praesentalis wspomina Jan Malalas (Ioannis Malalae chronographia, XIV, 46, rec. J. Thurn, Berolini et Novi Eboraci 2000, dalej: Malalas). Wyniesienie na to stanowisko miało nastąpić po ślubie z Leoncją. 
Zenon nie zdecydował się na odebranie Marcjanowi, swojemu szwagrowi stanowiska, choć zapewne miał świadomość, że stanowi on dla niego, ze względu na swoje rodzinne koligacje i majątek, potencjalne zagrożenie.

\section{Armatus}

Następcą Marcjana na stanowisku magistra militum praesentalis był Armatus, ale to nie Zenon był tym, który powierzył mu jako pierwszy to stanowisko.

Niewiele wiemy o pochodzeniu Armatusa ${ }^{7}$. Pewne jest, iż był on spokrewniony z cesarzową Weryną, żoną Leona I i Bazyliskosem, jej bratem. Najpewniej był ich siostrzeńcem ${ }^{8}$. Istnieje $w$ nauce hipoteza, iż ojcem Armatusa mógł być niejaki Zuzos, którego imię pojawia się jedynie w Vita S. Danieli w kontekście spisku przeciw Zenonowi ${ }^{9}$, matką zaś nieznana nawet z imienia siostra Weryny i Bazyliskosa.

Armatus wywodził się z rodziny o tradycjach wojskowych ${ }^{10}$, co z pewnością miało wpływ na jego losy. Pierwsza wzmianka dotycząca kariery Armatusa pochodzi z końca panowania Leona I, kiedy otrzymał, jak się sądzi, stanowisko magister militum per Thracias. Istnieją rozbieżności, co do datowania tego wydarzenia ${ }^{11}$. Nie mamy żadnych podstaw źródłowych, aby stwierdzić czym zasłużył na taki awans. Można sądzić, iż stała za nim cesarzowa Weryna, jego ciotka, która popierała swoich krewnych, ale tych, którzy dysponowali jakimiś talentami ${ }^{12}$, co wskazuje na to, że Armatus takowe, w jego przypadku wojskowe, posiadał i że zostały dostrzeżone.

$\mathrm{W}$ czasie pełnienia funkcji magister militum per Thracias Armatus thumił powstanie Gotów w Tracji, karząc buntowników obcięciem rąk ${ }^{13}$. Powszechnie uważa się, iż wspomniany bunt Gotów był następstwem zamordowania Aspara w $471 \mathrm{r}$., wszechwładnego wodza armii bizantyńskiej, człowieka będącego gwarantem interesów gockich na dworze. Za śmiercią Aspara stał sam cesarz Leon I. W odpowiedzi na to wydarzenie doszło do buntu kontyngentu gockiego w Konstantynopolu, którego dowódcą był Ostrys. Goci zostali zmuszeni do opuszczenia stolicy. Podnieśli jed-

7 Na temat Armatusa: PLRE II, s. 148-149; M. J. Leszka, Armatus: a story of Byzantine general from the 5th century, „Eos” 2000, nr 87, s. 335-343; Ch. Begass, Die Senatsaristokratie, s. 87-90.

8 M. Salamon, Basiliscus cum Romanis suis, [w:] Studia Moesiaca, t. 1, Poznań 1994, s. 189.

9 Żywot Daniela Stylity, s. 69; M. Salamon, Basiliscus, s. 188-189.

10 M. Salamon, Basiliscus, s. 187.

11 W PLRE II, s. 148. Wydarzenie to datowane jest na rok 469. M. Salamon (Basiliscus, s. 189) uważa, że jest to zbyt wczesna data. Jego zdaniem Armatus pełnił tę funkcję z pewnością w 471 r. Poprzednik Armatusa na tym stanowisku Anagastes jeszcze najprawdopodobniej w 470 r. je zajmował (PLRE II, S. 75).

12 M. Salamon, Basiliscus, s. 180-181.

13 Malchus, 9.4, [w:] The Fragmentary Classicising Historians of the Later Roman Empire. Eunapius, Olympiodorus, Priscus and Malchus, t. 2, tłum. i red. R. C. Blockley, Liverpool 1983 [dalej: Malchus]; M. Salamon, Basiliscus, s. 189; PLRE II, s. 148. 
nak do walki swoich pobratymców w Tracji ${ }^{14}$. I właśnie z tym powstaniem, jak się sądzi, borykał się Armatus, stosując radykalne metody zastraszania ludności. Nie wiemy kiedy Armatus przestał pełnić funkcję magister militum per Thracias. Najpóźniej musiało to nastąpić w 474 r., bowiem w tym roku potwierdzony jest na tym stanowisku Herakliusz z Edessy ${ }^{15}$. Po dymisji, jak można przypuszczać, Armatus przebywał w Konstantynopolu. Nie wiemy czy piastował jakiś urząd. Wydaje się, że był do początków 475 r. osobą prywatną, ale z pewnością cieszył się sporymi wpływami wśród stołecznej elity, co tłumaczyłoby dlaczego Bazyliskos, jego wuj zwrócił się do niego o pomoc w usunięciu cesarza Zenona ${ }^{16}$, obiecując $\mathrm{w}$ razie sukcesu stanowisko magistra militum praesentalis. Po ucieczce Zenona z Konstantynopola w styczniu 475 r. z obietnicy tej się wywiązał ${ }^{17}$.

Rządy Bazyliskosa nie cieszyły się jednak popularnością. Jego promonofizycka polityka religijna przyniosła opozycję ze strony ortodoksów, surowa polityka fiskalna również podkopywała jego pozycję. Zenon na terenie Izaurii gromadził siły, z którymi zamierzał ruszyć na Konstantynopol. Na jego stronę przeszli wodzowie armii wysłanej przeciw niemu. W tej sytuacji Bazyliskos zdecydował się na wysłanie przeciw oddziałom Zenona wojsk z Tracji, Konstantynopola, gwardii cesarskiej ${ }^{18}$, na czele której postawił Armatusa. W jego ręce oddał tym samym losy swego panowania. Armatus przed wyruszeniem na wyprawę przeciw Zenonowi złożyć miał przysięgę, iż nie zdradzi Bazyliskosa ${ }^{19}$. Jak się jednak okazało do zbrojnej rozprawy nie doszło. Przeciwnicy spotkali się w pobliżu Nicei w Bitynii ${ }^{20}$. Siły, które wiódł ze sobą Armatus przewyższały wojsko Zenona, z czego ten ostatni zdawał sobie sprawę i dlatego zamiast podejmować walkę spróbował pozyskać dla swojej sprawy ich wodza. Złożył mu propozycję dożywotniego sprawowania magisterium militum praesentalis oraz nadania tytułu cezara Bazyliskosowi, jego synowi, co gwarantować miało mu

14 P. J. Heather, Goths and Romans 332-489, Oxford 1991, s. 255 nn. Na temat motywów akcji Ostrysa patrz E. P. Glushanin, Voennaja, s. 132.

15 PLRE II, s. 541-542; cf. M. Salamon, Basiliscus, s. 189.

16 Ioannis Antiocheni Fragmenta quae Supersunt Omnia, 233, red. S. Mariev, Berolini et Novi Eboraci 2008 [dalej: Jan z Antiochii].

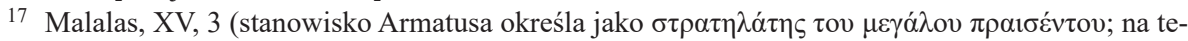
mat znaczenia tego tytułu: E. P. Glushanin, Voennaja, s. 142-143); Chronicon Paschale, red. L. Dindorf, t. 1, Bonnae 1832, s. 601 (donosi, że był nim w momencie wyruszania na wyprawę przeciw Zenonowi).

18 Malalas, XV, 5; Chronicon Paschale, s. 601; cf. Theophanes, Chronographia, AM 5969, red. C. de Boor, Lipsiae 1883 (dalej: Teofanes); Ioannis Zonarae Epitomae historiarum, XIV, 2. 23, t. 3, red. Th. Büttner-Wobst, Bonn 1897. Cf. E. P. Glushanin, Voennaja, s. 142-143.

19 Malalas, XV, 5; Chronicon Paschale, s. 601; Teofanes, AM 5969; cf. The Chronography of Gregory Abu'l-Faraj 1225-1283 ... known as Bar Hebraeus, tłum. E. A. Wallis Budge, t. 1, Amsterdam 1971, s. 70 [dalej: Bar Hebraeus]; The Chronicle of John, Bishop of Nikiou, LXXXVIII, 38, tłum. R. H. Charles, London 1916 [dalej: Jan z Nikiu; tu zamiast Armatus — Armalis; w dziele tym pojawia się również niejaki Serbatos jako składający przysięgę].

20 Teofanes. AM 5969; Zonaras XIV, 2. 23. 
następstwo po Zenonie ${ }^{21}$. Propozycja została przyjęta i Armatus przeszedł na stronę Zenona. Po powrocie do władzy cesarz wypełnił swoje zobowiązania. Armatus rzeczywiście dożywotnio pełnił powierzone mu stanowisko, został jednak zamordowany już w kilka miesięcy po odzyskaniu tronu przez Zenona ${ }^{22}$.

Jak z powyższego wynika stanowisko magistra militum praesentalis zostało użyte przez Zenona do pozyskania sojusznika, który pomógł mu odzyskać władzę. Talenty wojskowe Armatusa i doświadczenie, których mu, co prawda, nie brakowało nie miały w tym momencie specjalnego znaczenia. Ważne było to, iż dysponował on realną siłą wojskową, która gwarantowała Zenonowi powrót na tron, za co gotów był zapłacić każdą cenę.

\section{Martynian}

Martynian ${ }^{23}$ jest wzmiankowany jedynie w kontekście kampanii przeciw Ostrogotom w roku 478. Według Malchusa został wówczas wyznaczony przez Zenona na dowódcę wojsk i prawdopodobnie obdarzony stanowiskiem magistra militum praesentalis $^{24}$, które prowadzić miały działania przeciw Teodorykowi Strabonowi. Nie mamy żadnych informacji, dotyczących pochodzenia Martyniana i jego dotychczasowej kariery. Można jedynie domyślać się, że miał za sobą jakieś dowódcze doświadczenie. W innym razie wątpić należy, aby cesarz powierzył mu tak odpowiedzialne zadanie jakim było dowodzenie siłami, mającymi walczyć z tak niebezpiecznym przeciwnikiem, jakim był Teodoryk Strabon. Po tym, jak doszło do sojuszu tego ostatniego z Teodorykiem Amalem Zenon zdecydował się osobiście dowodzić wojskiem,

21 Malalas, XV, 5; Chronicon Paschale, s. 601; Procopius, De bello Vandalico, I, 7. 21, ed. Procopius. With English Translation by H. B. Dewing, t. 2, London 1916 (autor ten wyraźnie stwierdza, iż Bazyliskos miał zostać następcą Zenona; natomiast nie wspomina o funkcji magistra dla Armatusa); Teofanes, AM 5969; Bar Hebraeus, s. 69; Zonaras XIV, 2. 23, 27; cf. Evagrius, The Ecclesiastical History of Evagrius with the Scholia, III, 24, red. J. Bidez, L. Parmentier, Amsterdam 1964 [dalej: Ewagriusz].

22 Armatus był niewygodnym współpracownikiem dla Zenona. Jego pozycja była zbyt silna (Jan z Nikiu, LXXXVIII, 45). Armatus był nie tylko niebezpieczny dla samego cesarza, ale miał również na dworze innych wrogów, spośród których najgroźniejszym był Illus. Jemu Zenon zawdzięczał w znacznym stopniu powrót do władzy. Illus nie mógł patrzeć obojętnie jak rośnie w potęgę Armatus. Ewagriusz Scholastyk wyraźnie wskazuje, iż to właśnie Illus był odpowiedzialny za tragiczny koniec Armatusa (Ewagriusz, III, 24: Idąc za radą Illosa, zgładził Zenon także Armatosa... (tłum. Ewagriusz Scholastyk, Historia Kościoła, z języka greckiego przełożył S. Kazikowski, wstęp E. Wipszycka, Warszawa 1990, s. 134). Cf. m.in. R. Kosiński, The Emperor, s. 99-100; P. Crawford, Zeno, s. 125-126.

23 Na temat Martyniana patrz PLRE II, s. 730; Ch. Begass, Die Senatsaristokratie, s. 191.

24 Malchus (18.2) pisze, że Martynian został przez Zenona $\pi \rho \circ \beta \alpha \lambda o ́ \mu \varepsilon v o \varsigma \sigma \tau \rho \alpha \tau \eta \gamma o ́ v$. Nie ma więc pewności, że został on magistrem praesentalis. Za tym, że Martynian mógł nim być: PLRE II, s. 730. Ł. Jarosz, Teodoryk Strabon, „Zeszyty Naukowe Uniwersytetu Jagiellońskiego. Prace Historyczne” 2013, t. 140, nr 3, s. 225) uważa, że był on magistrem militum per Thracias. Można w to wątpić, ponieważ w tym samym fragmencie dzieła Malchusa, w którym jako strateg wymieniony jest Martynian, pojawia

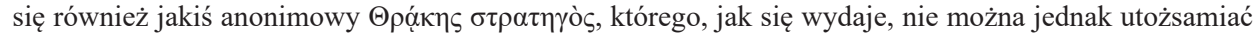
z Martynianem. 
co wzbudziło entuzjazm wśród żołnierzy. Po drobnych sukcesach cesarz wycofał się z osobistego dowodzenia, co z kolei spowodowało niezadowolenie wśród żołnierzy ${ }^{25}$. Martynian miał poradzić cesarzowi, by rozpuścić wojsko ${ }^{26}$. Świadczy to z jednej strony, że był on w tym czasie u boku cesarza, a z drugiej strony, że sam nie dysponował autorytetem, pozwalającym mu na zapanowanie nad niezadowoloną armią.

Być może fakt, iż Martynian nie jest wspominany w innych źródłach świadczy o tym, że nie był on przed rokiem 478 postacią znaczącą, dysponującą jakimś zapleczem politycznym. Gdyby tak było w rzeczywistości, to świadczyłoby to, o tym, że Zenon po doświadczeniach początków swoich rządów, a szczególnie uzurpacji Bazyliskosa chciał promować na stanowiska osoby, który swój awans zawdzięczałyby tylko jemu.

\section{Longin}

Kolejnym znanym nam magistrem militum praesentalis był Longin ${ }^{27}$, prawdopodobnie młodszy brat cesarza Zenona. O życiu Longina do roku 475 nie da się powiedzieć nic pewnego. Pierwsza wzmianka źródłowa dotyczącą Longina związana jest z rządami Bazyliskosa. Wiadomo, że znalazł się on wówczas w rękach Illusa, stając się jedną z gwarancji jego bezpieczeństwa, po tym jak Illus i jego brat Trokundes, zdecydowali się porzucić sprawę Bazyliskosa i przejść na stronę Zenona ${ }^{28}$. Longin znajdował się w rękach Illusa najpewniej do pierwszej połowy 485 r. Po uwolnieniu Zenon obdarzył go stanowiskiem magister militum praesentalis ${ }^{29}$. W 486 r. otrzymał on godność konsula, piastował ją ponownie w 490 r. Był również pierwszym członkiem senatu konstantynopolitańskiego. Wygląda na to, że Zenon tymi posunięciami chciał zrekompensować bratu lata niewoli, szczególnie że sam był za nie w dużej mierze odpowiedzialny. Powołanie Longina na stanowisko magistra militum praesentalis nie było, jak się wydaje, spowodowane jakimiś wojennymi potrzebami. Jedynym kluczem do tej nominacji było dążność Zenona do wyeksponowania Longina jako ce-

25 Na temat tej kampanii m.in.: R. M. Errington, Malchos von Philadelphia, Kaiser Zenon und die zwei Theoderche, „Museum Helveticum” 1983, t. 40, s. 100; P. Heather, Goths and Romans, s. 278280; M. Wilczyński, Germanie w stużbie zachodniorzymskiej w V w. n.e., Oświęcim 2018, s. 415-418; P. Crawford, Roman Emperor Zeno, s. 129-130.

26 Malchus, 18.3. Zbyt daleko, jak się wydaje, idzie Ł. Jarosz (Teodoryk, s. 225), przypisując Martynianowi poradzenie cesarzowi dojścia do porozumienia z Teodorykiem Strabonem. Malchus wspomina jedynie o radzie Martyniana w sprawie wojska. Jej przyjęcie przez cesarza musiało zaowocować podjęciem przez niego próby pokojowego rozwiązania konfliktu z Ostrogotami. I jedynie w takim kontekście można dopatrywać się wpływu Martyniana na dalsze kroki Zenona.

27 Na temat Longina patrz: PLRE II, s. 689-690; M. J. Leszka, Dzieje Longina, brata cesarza Zenona, [w:] Hortus Historiae. Księga pamiątkowa ku czci profesora Józefa Wolskiego w setna rocznicę urodzin, red. E. Dąbrowa, M. Dzielska, M. Salamon, S. Sprawski, Kraków 2010, s. 651-665; Ch. Begass, Die Senatsaristokratie, s. 181-182.

28 Szerzej na ten temat: M. J. Leszka, Dzieje, s. 652-655.

29 Malalas, XV, 12. 
sarskiego brata i zadośćuczynienie za lata niewoli. Kryterium kompetencji z pewnością nie było zastosowane. Nic nie wiemy o tym, aby zebrał jakieś doświadczenia jako wódz, a przynajmniej w ciągu dekady poprzedzającej swój awans.

\section{MAGISTRI MILITUM PRAESENTALIS \\ II ARMIA IN PRAESENTI}

\section{Trokundes}

Trokundes $^{30}$, jak już nadmieniałem powyżej, był bratem Illusa i jak można sądzić najbliższym, zaufanym i wiernym jego współpracownikiem. Pojawia się on na scenie historycznej w związku z uzurpacją Bazyliskosa. Po ucieczce Zenona do Izaurii nowy cesarz zdecydował się na wysłanie wojsk przeciw Zenonowi. Na ich czele postawił Illusa i właśnie Trokundesa. O jego wcześniejszych losach nie wiemy nic. Można jedynie podejrzewać, że dysponował jakimś doświadczeniem militarnym, skoro powierzono mu wraz z bratem tak odpowiedzialne zadanie jak ujęcie Zenona. Nie jesteśmy w stanie precyzyjnie określić jakie stanowiska powierzył Bazyliskos Illusowi i Trokundesowi, wysyłając ich przeciw Zenonowi i tym samym jaka była zależność między nimi — byli sobie równorzędni czy też, któremuś z nich powierzono naczelne dowództwo (jeśli tak, to raczej Illusowi)?

Nie wiemy, kiedy dokładnie rozpoczęła się ekspedycja Illusa i Trokundesa, ale zapewne nastąpiło to $\mathrm{w}$ niedługim czasie po przejęciu władzy przez Bazyliskosa, może wiosną 475 r. Działania Illusa i Trokundesa przeciągnęły się na rok następny, bowiem cel nie został osiągnięty. Zenon zamknął się w Shide ${ }^{31}$, jednej z niedostępnych twierdz izauryjskich, której wojska Illusa i Trokundesa nie były w stanie zdobyć. Najprawdopodobniej wiosną roku 476 doszło do wydarzenia, które zmieniło istniejący dotychczas układ sił. Oto Illus i Trokundes przeszli wraz z dowodzonym przez siebie wojskiem do obozu Zenona.

Zenon, przeciągając Illusa i Trokundesa na swoją stronę zobowiązał się do wynagrodzenia ich za to. $Z$ rozwoju wydarzeń wynika, że w grę wchodziło powierzenie im wysokich stanowisk państwowych. Illus, jak wiadomo, po usunięciu Bazyliskosa został magistrem officiorum, Trokundes zaś magistrem militum. Malalas, który jako je-

30 Na temat Trokundesa patrz: PLRE II, s. 1127-1128; M. J. Leszka, The Career of Flavius Appalius Illus Trocundes, „Byzantinoslavica” 2013, t. 71, s. 47-58 (wersja polska tego artykułu: Kariera Flawiusza Appaliusza Illusa Trokundesa. Z dziejów obecności izauryjskiej w Konstantynopolu w II połowie V w., [w:] W kręgu ikon władzy, ludzi oraz idei świata starożytnego, red. W. Kaczanowicz, A. A. Kluczek, N. Rogosz, A. Bartnik, Katowice 2014, s. 227-239); Ch. Begass, Die Senatsaritokratie, s. $250-251$.

31 Teofanes AM 5967; Zenon przebywał najpierw w twierdzy Ourba (ob. Uta), a potem w twierdza Shide (ob. Izvit), w której oblegany był przez Illusa i Trokundesa. Ta ostatnia twierdza położona była 1400 m. n.p.m. na północny zachód od Germanopola (K. Feld, Barbarische Bürger: die Isaurier und das Römische Reich, Berlin 2005, s. 32). 
dyny określa otrzymane przez Trokundesa stanowisko używa terminu $\sigma \tau \rho \alpha \tau \eta \lambda \alpha ́ \tau \eta \varsigma^{32}$. Najczęściej sądzi się, że Zenon wyznaczył Trokundesa naczelnym dowódcą wojsk bizantyńskich na Wschodzie. Tym, co uprawdopodobnia taki pogląd, jest fakt, że tuż po nominacji został on wysłany z zadaniem zajęcia Antiochii, miasta które było siedzibą magistra militum per Orientem.

Co do datowania wyznaczenia Trokundesa magistrem militum per Orientem $^{33}$, to należałoby wskazać na początek lata 476 r., tuż przed opanowaniem przez Zenona Konstantynopola, co nastąpiło w sierpniu tego roku. Trzeba zaznaczyć, że, co prawda, Zenon nie dysponował wówczas władzą nad stolicą, ale uważał się za legalnego władcę Imperium i zapewne nie widział żadnych przeszkód w podejmowaniu tego rodzaju decyzji ${ }^{34}$.

W końcu 479 lub, co bardziej prawdopodobne, w początkach 480 r. Trokundes doczekał się kolejnego awansu, a mianowicie został magistrem militum praesentalis, zastępując Teodoryka Strabona, którego Zenon pozbawił tego stanowiska za jego nielojalną postawę w związku z próbą uzurpacji Marcjana ${ }^{35}$. Czym zasłużył sobie Trokundes na taki awans? Niekoniecznie był to wyraz uznania dla jego militarnych sukcesów, o których, pomijając epizod z pochwyceniem Marcjana ${ }^{36}$, nic nie wiemy. Możliwe, że w ten sposób Zenon wyraził wdzięczność Illusowi, który doprowadził do stłumienie uzurpacji Marcjana, co pozwoliło utrzymać się Zenonowi na tronie. Możliwe też, że Illus po prostu wymógł na Zenonie nominację brata, chcąc wzmocnić swoją pozycję wobec cesarza. Przypomnieć w tym miejscu należy, że choć Illus współpracował z Zenonem, to jednocześnie obawiał się go, czego wyrazem było przetrzymywanie jako zakładników Longina, cesarskiego brata i Weryny, teściowej cesarza. Jest możliwe, że w związku z otrzymaniem stanowiska magistra militum praesentalis Trokundes otrzymał również godność patrycjusza ${ }^{37}$.

32 Malalas, XV, 5.

33 PLRE II, 1127 datuje to wydarzenie na rok 476/477.

34 Kwestię tę analizowałem w artykule: M. J. Leszka, The Career, s. 53.

35 Malchus, 22; R. M. Errington, Malchos von Philadelpheia, s. 108; P. J. Heather, Goths and Romans, s. 294; J. Prostko-Prostyński, Novae in the Times of Theodoric the Amal, [w:] Novae. Legionary Fortress and Late Antique Town, t. 1, A Companion to the Study of Novae, red. T. Derda, P. Dyczek, J. Kolendo, Warsaw 2008, s. 180; Ł. Jarosz, Teodoryk, s. 225-226. O uzurpacji Marcjana: Bunt Marcjana w Konstantynopolu (479), [w:] Z badań nad wczesnobizantyńskim Konstantynopolem, red. M. J. Leszka, K. Marinow, A. Kompa, Łódź 2011 (=Acta Universitatis Lodziensis. Folia Historica 87), s. 215-225.

36 Marcjan po stłumieniu wywołanego przez siebie buntu został uwięziony, i następnie wysłany przez cesarza Zenona na wygnanie. Według przekazu Jana z Antiochii (234. 4) w Cezarei Kapadockiej Marcjan miał uciec swoim strażnikom. Następnie udało mu się zebrać liczną grupę wieśniaków, z którą podjąć miał próbę zdobycia Ancyry w Galacji. Nie powiodła się ona, dzięki temu, że miasto zostało wcześniej obsadzone przez Trokundesa, który odparł atak ludzi Marcjana, a następnie doprowadził do jego pojmania i wysłania do twierdzy Papyrion, w której ten ostatni przebywał do czasu wybuchu uzurpacji Illusa i Leoncjusza (484). Na temat tych wydarzeń K. Twardowska, Cesarzowe, s. 188-189; K. Feld, Barbarische, s. 262; R. Kosiński, The Emperor Zeno, s. 105.

37 A. A. Čekalova (Senat i senatorskaja aristokratija Konstantinopola IV-pervaja polovina VII veka, Moskva 2010, s. 113) datuje to wydarzenie między 479 a 482 r. 


\section{MAGISTRI MILITUM PER ORIENTEM}

\section{Trokundes}

Pierwszym uchwytnym w źródłach magistrem militum per Orientem za rządów Zenona był przedstawiony powyżej Trokundes, brat Illusa. Swą funkcję sprawował zapewne do $479 \mathrm{r}$.

\section{Illus}

Kolejnym znanym nam magistrem militum per Orientem był wielokrotnie już wzmiankowany Illus ${ }^{38}$, który w chwili cesarskiej nominacji miał za sobą błyskotliwą karierę. Przez pewien czas był najważniejszym, aczkolwiek trudnym, sojusznikiem cesarza Zenona, szarą eminencją bizantyńskiego dworu. Pełnił funkcję magistra officiorum, był konsulem roku 478 i patrycjuszem. Miał za sobą bogate doświadczenia wojskowe, że wspomnę choćby pierwsze źródłowo potwierdzone. W 474 roku Zenon powierzył mu dowództwo nad oddziałem wojska, którego zadaniem było powstrzymanie Gotów Teodoryka Strabona operujących przeciw cesarstwu na terenie Tracji ${ }^{39}$. Nie wiadomo jakie stanowisko powierzył Illusowi Zenon, natomiast jedno jest pewne, że z wyznaczonego mu zadania ten pierwszy wywiązał się dobrze. Gockie niebezpieczeństwo zostało zażegnane.

Stanowisko magistra militum per Orientem Illus otrzymał od cesarza Zenona w szczególnych okolicznościach. Otóż w początkach lat osiemdziesiątych rozgorzał konflikt między Illusem a cesarzową Ariadną, żoną Zenona w kwestii uwolnienia jej matki - cesarzowej Weryny, wdowy po Leonie I. Illus nie chciał zgodzić się na uwolnienie matki Ariadny, czego następstwem był nieudany zamach na jego życie zorganizowany przez ludzi cesarzowej, za wiedzą i zgodą Zenona ${ }^{40}$. W konsekwencji tego wydarzenia Illus zdecydował się na opuszczenie Konstantynopola. Zanim to uczynił zażądał od Zenona, aby powierzył mu stanowisko magistra militum per Orientem, na co cesarz się zgodził. Illus po otrzymaniu stanowiska udał się do Antiochii. Dlaczego cesarz zgodził się na to? Tą sprawą zajmowałem się już w innym miejscu. Z tego względu pozwolę sobie jedynie na przedstawienie konkluzji zawartych tam wywodów. Wydaje się, że Zenon po nieudanym zamachu na Illusa nie był gotów do ostatecznej z nim rozprawy. Wynikało to z układu sił między nimi. Illus dysponował, jak można wnioskować z historii stłumienia przez niego buntowniczego wystąpienia Marcjana w 479 r., stosunkowo silnym zapleczem militarnym w stolicy i Zenon dlate-

38 Na temat Illusa poza wzmiankowanymi już pracami: A. Nagl, Illos, [w:] RE, Bd 9, 2, Stuttgart 1916, kol. 2532-2541; PLRE II, s. 586-590, Ch. Begass, Senatsaristokratie, s. 154-158.

39 Jan z Antiochii, 233.

40 Najpełniejszy opis wydarzeń: Malalas, XV, 13; Jan z Nikiu, LXXXVIII, 68-74; Teofanes, AM 5972. 
go nie chciał ryzykować otwartej konfrontacji, szczególnie że był zagrożony ze strony Ostrogotów. Obserwując na przestrzeni lat poczynania cesarza wobec Illusa można dojść do wniosku, że bez względu na sytuację nie dążył on do jawnego z nim konfliktu. Zawsze ukrywał się za poczynaniami innych i wypierał się jakichkolwiek związków z tymi, którzy starali się pozbawić życia Illusa. Ten ostatni z kolei mimo kolejnych akcji skierowanych przeciw sobie gotów był na kompromis. Tak rzecz się miała nawet po zamachu zorganizowanym przez Ariadnę. Ta pojednawcza postawa Illusa dawała Zenonowi nadzieję, że magister officiorum nie zechce w przyszłości przeciw niemu występować. Zgodził się na jego prośbę i pozwolił wyjechać na Wschód obdarzywszy wysokim stanowiskiem, bo wydawało mu się to dobrym rozwiązaniem. Nie musiał obawiać się, że zdesperowany Illus podejmie jakieś działania przeciw niemu, co, gdyby przebywał on w stolicy, mogło być niezwykle niebezpieczne. Wysyłając pobratymca na Wschód dawał mu, co prawda, swobodę działania, ale i sam ją również zyskiwał, mając także czas na przygotowanie się do ewentualnej konfrontacji lub na wyciszenie zaistniałego konfliktu. Dzięki temu zabiegowi, kiedy doszło do ostatecznego zerwania $\mathrm{z}$ Illusem cesarz był w stanie doprowadzić do skutecznego rozprawienia się z tym ostatnim.

Jak z powyższego wynika wyznaczenie Illusa na stanowisko magistra militum per Orientem zostało wymuszone na Zenonie i stanowiło zabieg obliczony na przynajmniej czasowe zneutralizowanie zagrożenia ze strony Illusa.

\section{Jan Scyta}

Jan Scyta ${ }^{41}$ był następcą Illusa i jego pogromcą. Nie dysponujemy żadną wiedzą o losach Jana do roku 482. Można jedynie wnosić, że do tego czasu jego kariera rozwijała się ścieżką wojskową.

Pierwszą wzmiankę o Janie Scycie znajdujemy u Jana z Antiochii. Historyk pisze, że cesarz Zenon wysłał przeciw Teodorykowi Amalowi, przywódcy Gotów, który grabił Macedonię i Tesalię, właśnie Jana Scytę i Moschianus ${ }^{42}$. Określa ich mianem strategów (strategoi). Mieli oni zastąpić Sabiniana, magister militum per Illyricum, straconego z rozkazu cesarza ${ }^{43}$. Przypuszcza się, że Jan mógł zostać wyznaczony na stanowisko magister militum per Illyricum, a Moschianus został comes rei militaris. Nie można wykluczyć, że mogło być też odwrotnie, jak i tego, że żaden z nich nie otrzymał stanowiska magistra militum. Z braku możliwości ustalenia czy Jan Scyta albo Moschianus pełnili funkcję magister militum per Illyricum pomijam ich w roz-

41 Na temat Jana: PLRE II, s. 602-603; Ch. Begass, Senatsaristokratie, s. 165-166; M. J. Leszka, John the Scythian - a slayer of usurpers and the Isaurians, Studia Ceranea 10, 2020, s. 383-397.

42 Jan z Antiochii, 236; cf. The Chronicle of Marcellinus, a. 482, tłum i koment. B. Croke, Sydney 1995 [dalej: Marcellin Komes]; Chronique de Michel le Syrien: Patriarche Jacobite d'Antioche (11661198), IX, 6, red., tłum. J.-B. Chabot, t. 2 (livre VIII-XI), Paris 1901. Na temat Moschianusa: PLRE II, s. 766.

43 Jan z Antiochii, 236. Cf. M. Wilczyński, Germanie, p. 423-424. O Sabinianie: PLRE II, s. 967. 
ważaniach dotyczących powodów powierzania jej przez Zenona. O działaniach Jana Scyty i Moschianusa wiadomo tyle, że nie byli w stanie powstrzymać Teodoryka przed zdobyciem i złupieniem Larissy ${ }^{44}$. Kampania przeciw Teodorykowi, choć zapewne nie przyniosła Janowi Scycie jakichś wielkich sukcesów, to na pewno go nie skompromitowała, skoro w niedługi czas potem w roku 483 r. $^{45}$ lub $484^{46}$ cesarz powierzył mu stanowisko magister militum per Orientem, którego pozbawił Illusa, po tym jak ten ostatni odmówił wydania cesarzowi jego brata Longina. Cesarz wypędził wówczas z Konstantynopola związanych z Illusem ludzi, a ich majątek przekazał izauryjskim miastom. Illus zdecydował się na otwarty bunt przeciw cesarzowi ${ }^{47} \mathrm{i}$ doprowadził 19 lipca 484 r. do proklamowania cesarzem Leoncjusza. Zadanie stłumienia wystąpienia Illusa i Leoncjusza Zenon powierzył Janowi Scycie. Nie znamy motywacji cesarza przy powierzaniu Janowi stanowiska magistra militum per Orientem, ale nie ma wątpliwości, że musiał darzyć go zaufaniem i dobrze oceniać jego umiejętności jako wodza. W innym przecież razie nie oddałby w jego ręce losów swojego panowania. Niepowodzenia Jana Scyty w zmaganiach z Illusem i Leoncjuszem, względnie jego zdrada mogły zaowocować przecież utratą przez Zenona tronu. Być może to cesarskie zaufanie dla Jana wypływało z tego, że swoją karierę zawdzięczał on tylko cesarzowi $^{48}$ i nie był powiązany z środowiskiem Illusa. Zenon nie zawiódł się. Jan pozostał mu wierny i doprowadził do spacyfikowania powstania Illusa i Leoncjusza.

\section{MAGISTRI MILITUM PER ILLYRICUM}

\section{Onulf (Onoulphus)}

Onulf (Onoulphus) ${ }^{49}$ był synem Edekona i starszym bratem Odoakra. Doświadczenie wojskowe zebrał u boku ojca, walcząc z Ostrogotami. Po klęsce koalicji antygockiej, w skład której wchodzili m.in. Skirowie i Bizantyńczycy, w bitwie nad rzeką Boila w Panonii w 469/470 r. prawdopodobnie przyłączył się do wycofujących się Bizantyńczyków i dotarł do Konstantynopolu, gdzie po jakimś czasie znalazł się pod

44 Marcellin Komes, a. 482. 2.

45 Np. H. Elton, Illus and the Imperial Aristocracy under Zeno, „Byzantion” 2000, t. 70, s. 399; R. Kosiński, The Emperor Zeno, s. 147.

46 Np. M. Salamon, Pamprepiusz z Panopolis - pisarz, profesor, polityk, obrońca pogaństwa w cesarstwie wschodnim, [w:] Studia Classica et Byzantina. Alexandro Krawczuk oblata, Kraków 1996, s. 182; K. Feld, Barbarische Bürger, s. 269.

47 Na temat konfliktu między Zenonem a Illusem patrz: M. J. Leszka, Kilka uwag na temat Illusa Izauryjczyka w latach 479-484, „Meander” 2007, nr 42, s. 103-105.

48 Cf. E. P. Glushanin, Voennaja, s. 53.

49 Na jego temat: A. Nagl, Onoulf, [w:] RE, Bd 18, 1, Stuttgart 1939, kol. 526-527; PLRE II, s. 806; M. Wilczyński, Germanie, s. 239-244. Intensywną dyskusję w nauce wzbudziła kwestia ewentualnego spokrewnienia Onulfa nie tylko z Odoakrem, ale i Armatusem. Na ten temat M. Wilczyński, Germanie, s. 240-241 (tam też literatura dalsza przedmiotu). 
opieką Armatusa, który obdarował go majątkiem i zadbał o karierę. Dzięki jego wpływom został komesem wojskowym, a później magistrem militum per Illyricum $^{50}$.

Nie jest pewne kiedy Onulf został magistrem militum per Illyricum. O powierzeniu mu tego stanowiska pisze jedynie Malchus, który wiąże ten fakt z wpływami Armatusa. Oznaczałoby to, że stało się to albo za panowania Bazylikosa, albo tuż po odzyskaniu przez Zenona władzy (sierpień 476 r. ), w każdym razie przed śmiercią Armatusa, która nastąpiła w końcu 476 lub w początkach 477 r. ${ }^{51}$ Wynika z tego, że Zenon albo jedynie zaakceptował Onulfa jako magistra militum per Illyricum, a jego awans miał miejsce za Bazyliskosa. albo sam powołał go na to stanowisko. W każdym razie w jednym i w drugim przypadku za wyniesieniem Onulfa stał Armatus, a decyzja cesarza może była łatwiejsza do podjęcia, ponieważ Onulf był człowiekiem związanym z wojaczką i dysponującym doświadczeniem w tym zakresie ${ }^{52}$. Sam Onulf nie wykazał się lojalnością wobec swojego promotora. Źródła czynią go odpowiedzialnym za jego śmierć ${ }^{3}$. Po śmierci Armatusa Onulf pozostawał na stanowisku magistra militum per Illyricum niezbyt długo. Wiemy, że w 479 r. zajmował je już Sabinian Wielki.

\section{Sabinian Wielki}

Następcą Onulfa został w 479 r., jak wspomniałem powyżej, Sabinian ${ }^{54}$. O jego karierze przed objęciem tego stanowiska nie wiemy nic, choć można sądzić, że miała ona charakter wojskowy. O tym świadczyć może fakt, że, jak wspomina Malchus, w chwili nominacji miał u swojego boku prywatny oddział wojska ${ }^{55}$. Na pewno wskazuje to również, że był osobą stosunkowo majętna, skoro mógł go utrzymywać. Jego nominacja wiąże się z kolejnym etapem konfliktu z Teodorykiem Amalem ${ }^{56}$. Wiemy, że odebrał ją w Edessie, w Macedonii z rąk Adamancjusza, patrycjusza i swego czasu prefekta Konstantynopola oraz od Filoksenusa, cesarskiego posła do Gotów ${ }^{57}$. Sabinian zapisał się jako przeciwnik negocjacji pokojowych prowadzonych z ramie-

50 Malchus, 9.4.

51 Dziwi nieco datowanie przez autorów PLRE początków pełnienia przez Onulfa stanowiska magistra militum od ok. 477, co sugerowałoby, że jego wyniesienie związane byłoby ze śmiercią Armatusa, co sprzeczne jest z przekazem Malchusa.

52 Cf. M. Wilczyński, Germanie, s. 242.

53 Jan z Antiochii, 232.1, Focjusz, kod. 78: Armatos [...] zostat skazany na śmierć z wyroku Onulfosa (tłum. Focjusz, Biblioteka, tom 1, Kodeksy 1-150, z jęz. greckiego przełożył, wstępem i komentarzem opatrzył O. Jurewicz, Warszawa 1986, s. 115).

54 Na temat Sabiniana Wielkiego: PLRE II, s. 967.

55 Malchus, fr. 20, w. 132.

56 Na temat ówczesnego stanu stosunków bizantyńsko-gockich: M. Wilczyński, Germanie, s. 418422.

57 Malchus, 20, w. 127-130. Cf. Marcellin Komes, a. 479.1 (Sabinianus Magnus Illyricianae utrius-

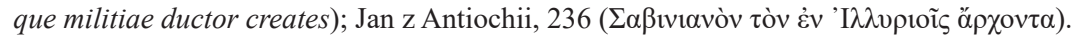


nia cesarza przez Adamancjusza ${ }^{58}$, zwycięski wódz ${ }^{59}$ i obrońca rzymskich tradycji państwowych ${ }^{60}$.

Przedstawione powyżej informacje prowadzą do wniosku, że decyzja cesarza Zenona o powierzeniu Sabinianowi stanowiska magistra militum per Illyricum związana była z jego wcześniejszymi dokonaniami w sferze wojskowej, o których niestety nic konkretnego nie da się powiedzieć.

\section{MAGISTRI MILITUM PER THRACIAS}

\section{Herakliusz}

Jest możliwe, że Herakliusz ${ }^{61}$ był pierwszym magistrem militum wyznaczonym przez Zenona. Jego aktywność na tym stanowisku obserwujemy w roku 474 r. Pochodził on z Edessy. Jego kariera miała charakter wojskowy. Źródła odnotowują jego udział jako komesa rei militaris w wyprawie wojsk bizantyńskich zorganizowanej dla wsparcia Lazów przeciw Persom i Iberom. W 468 r. uczestniczył w wyprawie dowodzonej przezBazyliskosa przeciw Wandalom ${ }^{62}$. Wydaje się, że bogate doświadczenia militarne Herakliusza stanowiły podstawę jego wyboru na magistra militum per Thracias. Miał on dowodzić wojskami bizantyńskim operującymi przeciw siłom Teodoryka Strabona ${ }^{63}$.

Wysłany przeciw Teodorykowi Strabo, został pobity i znalazł się w niewoli. Dowodzenie w walkach z Gotami przejął Illus, który starał się wykupić Herakliusza. Ostatecznie został już po wykupieniu zamordowany albo koło Arkadiopola, albo w pobliżu Chersonezu przez Gotów, którzy nie zapomnieli mu jego poprzednich okrucieństw.

58 Malchus, 20, w. 148-153. Sabinian nie chciał złożyć przysięgi gwarantującej bezpieczeństwo zakładnikom gockim. Zaatakował Gotów w czasie prowadzonych przez Adamancjusza negocjacji (Malchus, 20. w. 226nn).

59 O zwycięstwie Sabiniana nad Gotami: Malchus, 20, w. 226-248. Cf. M. Wilczyński, Germanie, S. 422 .

60 Marcellin Komes, a. 479.1: Był on [Sabinian] tak biegły w zarzadzaniu i utrzymywaniu dyscypliny $w$ sferze wojskowej, że można by go porównać do dawnych rzymskich wodzów (przekł. — M. J. Leszka, S. Wierzbiński, Komes Marcellin, vir clarissimus. Historyk i jego dzieło, Łódź 2021, w druku); a. 481.2: Śmierć [...] zabrała Sabiniana Wielkiego, nim ten zdołat przynieść ulgę umęczonemu cesarstwu. Nawiasem mówiąc Sabinian miał zostać zamordowany z rozkazu cesarza Zenona (Jan z Antiochii, fr. 236), co może sugerować, że ten poczuł się zagrożony rosnącym autorytetem Sabiniana.

61 PLRE II, s. 541-542.

62 Priscus, Fragmenta, 53. 3, [w:] The Fragmentary Classicising Historians of the Later Roman Empire. Eunapius, Olympiodorus, Priscus and Malchus, t. 2, tłum. i red. R. C. Blockley, Liverpool 1983.

63 Malchus, 5. 3. 


\section{Leoncjusz}

O karierze Leoncjusza ${ }^{64}$ do czasu otrzymania stanowiska magistra militum per Thracias wiemy tyle, że miała ona charakter wojskowy ${ }^{65}$. Nie wiemy, kiedy Leoncjusz otrzymał to stanowisko. Wydaje się, że w grę w zasadzie może wchodzić schyłek lat siedemdziesiątych i początek osiemdziesiątych. $Z$ okresu poprzedzającego wskazany czas znamy nam magistrem militum per Thracias jest przedstawiony powyżej Herakliusz, który pełnił to stanowisko w 474 r. W źródłach wspominany jest jeszcze w związku z wydarzeniami roku 478 jakiś magister militum per Thracias, ale bez wskazania imienia, którego z pewnością nie można utożsamiać z Leoncjuszem ${ }^{66}$. Wynika z tego, że Leoncjusz mógł najwcześniej otrzymać to stanowisko od cesarza Zenona w 478 r. Nie jest oczywiste, że pełnił je w 484 r., jak się dość powszechnie sądzi ${ }^{67}$. Teofanes, który jako jedyny podaje informację o pełnieniu przez Leoncjusza naczelnego dowództwa w Tracji, praktycznie w jednym zdaniu zamieszcza wszystko to, co o nim wiedział lub uznał za ważne. Ze zdania tego wynika jedynie tyle, że w jakimś momencie swojego życia był Leoncjusz magister militum per Thracias. Trzeba zauważyć, że informacja o Leoncjuszu u Teofanesa pojawia się nie w kontekście wydarzeń z roku 484, a w związku z opuszczeniem przez Illusa Konstantynopola, co datuje się na 481/482 r. Nie wiemy, kto był bezpośrednim następcą Leoncjusza na tym stanowisku. Następny uchwytny źródłowo magister militum per Thracias — Julian znany jest dopiero z początków rządów Anastazjusza ${ }^{68}$.

Wracając do kwestii kariery Leoncjusza trzeba odnotować fakt, że został on, zapewne za swoje wojskowe dokonania, obdarowany przez cesarza tytułem patrycjusza oraz konsula (honorowego) ${ }^{69}$. Także i w tym przypadku nie wiemy, kiedy to się sta-

64 Na temat Leoncjsza patrz: PLRE II, s. 670-671 (s. v. Leontius 17); Ch. Begass, Die Senatsaristokratie, s. 175-177. O karierze Leoncjusza do roku 481/482 pisałem szerzej w tekstach: On Leontius ' Origin and Career up until the Year 481/482, „Piotrkowskie Zeszyty Historyczne” 2020, nr 21.3, s. 9-18 i O Leoncjuszu i jego zmaganiach o cesarski tron $w$ latach 484-488. Raz jeszcze, „Przegląd Nauk Historycznych" 2021, nr 20.1, s. 47-72.

65 Teofanes, AM 5972. Wątpliwości E. W. Brooksa (The Emperor Zenon and the Isaurians, „The English Historical Review" 1893, t. 8, s. 226), co do pełnienia przez Leoncjusza stanowiska magister militum per Thracias są słabo uzasadnione. Autor ten twierdzi, że Teofanes się pomylił, bo takiej informacji nie ma w jego podstawowym dla tej kwestii źródle, czyli Chronografii Jana Malalasa. Cf. M. J. Leszka, O Leoncjuszu, s. 51-52.

66 Malchus, 15-16. Por. PLRE II, s. 1223.

67 PLRE II, s. 670; por. uwagi Macieja Salamona: Pamprepiusz, s. 183, przyp. 95.

68 PLRE II, s. 639. Julian znany jest jedynie ze wzmianki w Kronice Marcellina Komesa, a. 493. Autor odnotowuje jego śmierć w walce ze Scytami. Prawdopodobnie pod tym etnonimem kryją się Bułgarzy. Ze wzmianki tej wynika, że Julian pełnił to stanowisko już jakiś czas, ale czy był bezpośrednim następcą Leoncjusza, tego nie da się dowieść.

69 Teodor Lektor (Theodoros Anagnostes, Kirchengeschichte, Epitome, hrsg. G. C. Hansen, Berlin 1995), 437. Na listach konsulów imienia Leoncjusza nie ma; por. S. R. Bagnall, A. Cameron, R. S. Schwartz, A. Klaas Worp, Consuls of the Later Roman Empire, Atlanta 1987, s. 714. 
ło. Gdyby wiązać to $\mathrm{z}$ pełnieniem stanowiska dowódcy wojsk w Tracji, to trzeba by wskazać na czasy panowania Zenona.

Wydaje się, że przy powierzeniu Leoncjuszowi stanowiska magistra militum brał pod uwagę jego wojskowe doświadczenie i jakieś militarne dokonania, o których jednak nie jesteśmy w stanie nic konkretnego powiedzieć.

\section{PODSUMOWANIE}

Przegląd dostępnych informacji, dotyczących powoływania magistrów militum (praesentalis, per Orientem, per Illyricum, per Thracias) przez Zenona prowadzi do wniosku, że w tym względzie kierował się on względami natury wojskowej, jak i politycznej, a jego działania w tym zakresie stosunkowo często były reakcją na sytuację, a nie swobodnym wyborem. Stanowiska te były środkiem do pozyskiwania lub wynagradzania ludzi, których wsparcie było z jakichś względów potrzebne cesarzowi.

Najwyższe stanowiska dowódcze stosunkowo często rozdawane były członkom cesarskiej rodziny czy rodzin wpływowych osobistości na dworze cesarskim względnie ich protegowanym. Trzeba zaznaczyć, że kandydaci na magistrów militum dysponowali najczęściej jakimś wojskowym doświadczeniem, ale nie musiało być ono bardzo bogate. W każdym razie to ono było szczególnie brane pod uwagę, kiedy cesarz mógł dokonać swobodnego wyboru nowego magistra militum. Wówczas też sięgał po osoby, które nie dysponowały jakimiś wpływami i zawdzięczały swoje wyniesienie jedynie cesarskiej woli.

\section{BIBLIOGRAFIA}

\section{Źródla}

Chronicon Paschale, red. L. Dindorf, t. 1, Bonnae 1832.

Chronique de Michel le Syrien: Patriarche Jacobite d'Antioche (1166-1198), thum. i red. J.-B. Chabot, t. 2 (livre VIII-XI), Paris 1901.

Focjusz, Biblioteka, t. 1, Kodeksy 1-150, z jęz. greckiego przełożył, wstępem i komentarzem opatrzył O. Jurewicz, Warszawa 1986.

Ioannis Antiocheni Fragmenta quae Supersunt Omnia, red. S. Mariev, Berolini et Novi Eboraci 2008.

Ioannis Malalae chronographia, red. J. Thurn, Berolini et Novi Eboraci 2000.

Ioannis Zonarae Epitomae historiarum, t. 3, red. Th. Büttner-Wobst, Bonn 1897.

Malchus, [w:] The Fragmentary Classicising Historians of the Later Roman Empire. Eunapius, Olympiodorus, Priscus and Malchus, t. 2, thum. i red. R. C. Blockley, Liverpool 1983.

Priscus, Fragmenta, [w:] The Fragmentary Classicising Historians of the Later Roman Empire. Eunapius, Olympiodorus, Priscus and Malchus, t. 2, thum. i red. R. C. Blockley, Liverpool 1983, s. 222-401.

Procopius, De bello Vandalico, [w:] Procopius. With English Translation by H. B. Dewing, t. 2, London 1916.

The Chronicle of John, Bishop of Nikiou, thum. R. H. Charles, London 1916.

The Chronography of Gregory Abu'l-Faraj 1225-1283... known as Bar Hebraeus, thum. E. A. Wallis Budge, t. 1, Amsterdam 1971.

The Chronicle of Marcellinus, thum. i koment. B. Croke, Sydney 1995. 
The Ecclesiastical History of Evagrius with the Scholia, red. J. Bidez, L. Parmentier, Amsterdam 1964 (Ewagriusz Scholastyk, Historia Kościoła, z języka greckiego przełożył S. Kazikowski, wstęp E. Wipszycka, Warszawa 1990).

Theodoros Anagnostes, Kirchengeschichte, Epitome, red. G. C. Hansen, Berlin 1995.

Theophanes, Chronographia, red. C. de Boor, Lipsiae 1883.

Vita S. Danielis Stylitae, red. H. Delehaye, Analecta Bollandiana 37, 1913, s. 121-229.

\section{Opracowania}

Bagnall S. R., Cameron A., Schwartz R. S., Klaas Worp A., Consuls of the Later Roman Empire, Atlanta 1987.

Begass Ch., Die Senatsaristokratie des oströmischen Reiches, ca. 457-518. Prosopographische sozialgeschichtliche Untersuchungen, München 2018.

Brooks E. W., The Emperor Zenon and the Isaurians, „The English Historical Review” 1893, t. 8, s. 209238.

Čekalova A. A., Senat i senatorskaja aristokratija Konstantinopola IV-pervaja polovina VII veka, Moskva 2010.

Crawford P., Roman Emperor Zeno: The Perils of Power Politics in Fifth-century Constantinople, Yorkshire-Philadelphia 2019.

Demandt A., Magister militum, [w:] Paulys Realencyclopädie der classischen Altertumswissenschaft. Supplementband 12, Stuttgart 1970, kol. 553-790.

Durliat J., Magister militum - stratelates dan l'Empire Byzantin (VIe-VIIe siècles), „Byzantinische Zeitschrift" 1979, t. 72, s. 306-320.

Ensslin W., Marcianus 35, [w:] Paulys Realencyclopädie der classischen Altertumswissenschaft, Bd. 14XIV, 2, Stuttgart 1956, kol. 1519.

Errington R. M., Malchos von Philadelphia, Kaiser Zenon und die zwei Theoderche, „Museum Helveticum” 1983 , t. 40 , s. $82-110$.

Feld K., Barbarische Bürger: die Isaurier und das Römische Reich, Berlin 2005.

Glushanin E. P., Voennaja znat' rannej Vizantii, Barnaul 1991.

Heather P., Goths and Romans 332-489, Oxford 1991.

Jarosz Ł., Teodoryk Strabon, Zeszyty Naukowe Uniwersytetu Jagiellońskiego. „Prace Historyczne” 2013, t. 140 , nr 3, s. 213-227.

Kosiński R., Początki kariery Tarasikodissy-Zenona, [w:] Byzantina Europea. Księga jubileuszowa ofiarowana Profesorowi Waldemarowi Ceranowi, Łódź 2007, s. 289-304.

Kosiński R., The Emperor Zeno. Religion and Politics, Cracow 2010.

Leszka M. J., Armatus: a story of Byzantine general from the 5th century, „Eos” 2000, nr 87, s. 335343.

Leszka M. J., Bunt Marcjana w Konstantynopolu (479), [w:] Z badań nad wczesnobizantyńskim Konstantynopolem, red. M. J. Leszka, K. Marinow, A. Kompa, Łódź 2011 (=Acta Universitatis Lodziensis. Folia Historica 87), s. 215-225.

Leszka M. J., Dzieje Longina, brata cesarza Zenona, [w:] Hortus Historiae. Księga pamiatkowa ku czci profesora Józefa Wolskiego w setna rocznicę urodzin, red. E. Dąbrowa, M. Dzielska, M. Salamon, S. Sprawski, Kraków 2010, s. 651-665.

Leszka M. J., Empress-Widow Verina's Political Activity during the Reign of Emperor Zeno, [w]: Mélanges d'histoire byzantine offerts à Oktawiusz Jurewicz à l'occasion de son soixante-dixième Anniversaire, red. W. Ceran, Łódź 1998, s. 128-136.

Leszka M. J., Illus Izauryjczyk wobec uzurpacji Bazyliskosa, Acta Universitais Lodziensis. „Folia Historica" 2005 , t. 80 , s. $45-49$.

Leszka M. J., John the Scythian — a Slayer of usurpers and the Isaurians, „Studia Ceranea” 2020, t. 10, s. 383-397.

Leszka M. J., O Leoncjuszu i jego zmaganiach o cesarski tron w latach 484-488. Raz jeszcze, „Przegląd Nauk Historycznych" 2021, t. 20.1, s. 47-72. 
Leszka M. J., On Leontius' Origin and Career up until the Year 481/482, „Piotrkowskie Zeszyty Historyczne" 2020 , nr 21.3, s. 9-18.

Leszka M. J., The Career of Flavius Appalius Illus Trocundes, „Byzantinoslavica” 2013, t. 71, s. 47-58 [wersja polska artykułu: Kariera Flawiusza Appaliusza Illusa Trokundesa. Z dziejów obecności izauryjskiej w Konstantynopolu w II polowie $V$ w., [w:] $W$ kreggu ikon władzy, ludzi oraz idei świata starożytnego, red. W. Kaczanowicz, A. A. Kluczek, N. Rogosz, A. Bartnik, Katowice 2014, s. $227-$ 239].

Leszka M. J., Wierzbiński S., Komes Marcellin, vir clarissimus. Historyk i jego dzieło, Łódź 2021 (w druku).

Martindale J. R., Prosopography of the Later Roman Empire, t. 2 A.D. 395-527, Cambridge 1980.

A. Nagl, Illos, [w:] Paulys Realencyclopädie der classischen Altertumswissenschaft, Bd. 9, 2, Stuttgart 1916, kol. 2532-2541.

Nagl A., Onoulf, [w:] Paulys Realencyclopädie der classischen Altertumswissenschaft, Bd. 18, 1, Stuttgart 1939, kol. 526-527.

Poguntke A., Das römische Heermeisteramt im 5. Jahrhundert. Überlegungen zum Verhältnis zwischen Kaiser und Heermeister in Ost und West, [w:] Osten und Westen 400-600 n. Chr. Kommunikation, Kooperation und Konflikt, red. C. Föller, F. Schulz, Stuttgart 2016, s. 239-262.

Prostko-Prostyński J., Novae in the Times of Theodoric the Amal, [w:] Novae. Legionary Fortress and Late Antique Town, t. 1, A Companion to the Study of Novae, red.: T. Derda, P. Dyczek, J. Kolendo, Warsaw 2008, s. 141-157.

Salamon M., Basiliscus cum Romanis suis, [w:] Studia Moesiaca I, Poznań 1994, s. 179-196.

Salamon, Pamprepiusz z Panopolis - pisarz, profesor, polityk, obrońca pogaństwa w cesarstwie wschodnim, [w:] Studia Classica et Byzantina. Alexandro Krawczuk oblata, Kraków 1996, s. 163-195.

Twardowska K., Cesarzowe bizantyńskie 2 pot. V w. Kobiety $i$ wtadza, Kraków 2009.

Wassiliou-Seibt A.-K., From magister militum to strategos: the evolution of the highest military com-

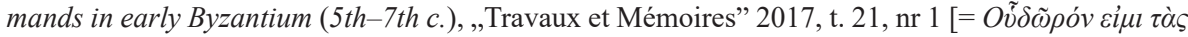

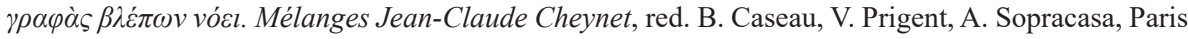
2017], s. 789-802.

Wilczyński M., Germanie w stużbie zachodniorzymskiej w Vw. n.e., Oświęcim 2018. 